\title{
Right to be a Surrogate: Biological, Constitutional and Economic Perspectives
}

\author{
Meghna Borah, ${ }^{\dagger}$ Arup Kumar Hazarika** and Unmilan Kalitā
}

\section{Abstract}

For the survival of all forms of life, procreation is essential. However, natural procreation is not always scientifically possible. As such, the practice of surrogacy and the use of Assisted Reproductive Techniques have become more widely recognised and accepted in societies all over the world. However, various complex and controversial issues are bounded in such practices. The Surrogacy (Regulation) Bill, 2019 introduced by Government of India makes an attempt to eradicate some of those issues associated with surrogacy.

Nevertheless, the legislation seems to be in derogation to the Constitution of India and universal human rights. This study is designed to substantiate in detail the right to be a surrogate in light of the constitutional mandate along with an evaluation of the eligibility criteria to be a surrogate and its consequences with regard to the existing legal framework. Besides, the economic perspective of exploitation of surrogates via banning of commercial surrogacy has been briefly discussed. The discussion under this study is expected to put forward an essential perspective to the right to be a surrogate in relation to a woman's right to life and personal liberty. Further, prohibiting commercial surrogacy may push practicing surrogates towards other economically unrewarding, poorly regulated and potentially hazardous forms of employment or even make them subject to human trafficking. Therefore, recognition of the right to be a surrogate vis-à-vis the Surrogacy (Regulation) Bill, 2019, would help in avoiding blatant miscarriage of universal justice while upholding the supremacy of the Constitution of India.

Keywords: Surrogacy; Legislative Framework; Trafficking; Assistive Reproductive Technology; Citizens' Rights; Surrogacy (Regulation) Bill 2019; India

\footnotetext{
† Jnanadabhiram Barooah Law College, Guwahati, India

¥Department of Zoology, Cotton University, Guwahati, India

${ }^{*}$ Corresponding Author, Email: arup.hazarika@cottonuniversity.ac.in

'Department of Economics, Cotton University, Guwahati, India

(C) 2020 Borah et al. This is an Open Access article distributed under the terms of the Creative Commons Attribution License (http://creativecommons.org/licenses/by/2.0), which permits unrestricted use, distribution, and reproduction in any medium, provided the original work is properly cited.
} 


\section{Introduction}

Since ancient times, the primary way of procreation is accomplished through the social institution of marriage and family (Kaur, 2015). Many childless couples experience severe strain in their interpersonal relationships which often lead to personal distress and periods of existential crisis. As a result of this, they opt for surrogacy as an alternative in order to beget a child genetically related to them. The word 'surrogate' has been derived from the Latin word 'surrogatus' which means substitution or replacement (Kusum, 2013). Surrogacy is defined as a practice where a child is given birth by a woman for an intending couple (Sagar, 2017). A surrogate or surrogate mother is referred to as a woman who agrees to carry and deliver a child on behalf of another couple. In other words, the surrogate carries the child for a full term and after the birth of the child, renounces all her parental rights over the child and hands her/his over to the intended couple or the individual concerned.

With the objective to beget a genetically related child, the practice of surrogacy is gaining popularity whereby a woman is hired to beget a child which is handed over to the intended parent(s). Over a past few years, with the colossal progression in technology, the practice of surrogacy has expanded rapidly and has promulgated an affair of concern, and thus, the practice of renting a womb is growing like industry by leaps and bounds. Such unchecked growth has made governments introduce several legislations which pertain to restrictions on who can be a surrogate, to what extent surrogacy can be practiced, who are the intended parents and whether an income can be earned through surrogacy. However, these legislations often miss out in elaborating the rights of a surrogate, more importantly, the right to 'be' a surrogate (Van den Akker, 2017). It is well known that the rights of underprivileged sections as transgender people and surrogates are often overlooked in legislative designs (Rwabihama, 2020). Debates on their rights have often dominated the agenda of Parliamentary discussions with no avail (Watson, 2016). In the case of the Indian surrogate, past legislations have failed to address their right to personal liberty and right to dignity in being a surrogate (Vincent \& Aftandilian, 2013). Indeed, the surrogacy market in India is approximately USD 2.5 billion, with thousands of foreign couples availing the country's inexpensive surrogacy services ever year (Reddy, 2020). This affair has a marked history of human trafficking and labour exploitation (Qadeer, 2010). For instance, surrogates are paid between a meagre INR 50,000 to INR 500,000, whereas clinics pocket millions of dollars (Ganapathy, 2019). Moreover, these so-called surrogacy clinics, besides being involved in illegal and unhealthy surrogacy practices, often act as façades for brokers involved in women and child trafficking (Pande, 2014).

The draft Surrogacy (Regulation) Bill, 2019 was introduced in the Parliament of India to prevent such exploitation of surrogates. It puts an end to commercial surrogacy in India, allowing only altruistic surrogacy wherein no monetary compensation would be provided to surrogate mothers other than healthcare expenses (The Surrogacy (Regulation) Bill, 2019). This Bill, although noteworthy in its intentions to end 'surrogacy for profit-making' in India, fails to address the constitutional rights of women as citizens who have the right to decide their occupation and thus, the right to be a surrogate. This study is an attempt to examine whether the right to be a surrogate in the proposed legislation is constitutional. We have tried to identify whether the eligibility criteria mentioned in the proposed legislation is in derogation to the regulations laid by international conventions. Further, this research probes the economic implications as to whether commercial surrogacy is exploitative labour. As such, the ensuing sections include an overview of the Indian surrogacy landscape, and features of the Surrogacy (Regulation) Bill, 2019, an analysis of the Bill vis-à-vis the right to be a surrogate, followed by the economic consequences of practising surrogacy in India. 
Insight into different facets of surrogacy in India

Surrogacy in India dates back to the birth of Kanupriya alias Durga in Calcutta on 03 October 1978 (Kumar, 2004). She was the world's second and India's first IVF (in-vitro fertilisation) baby, born two months after the world's first IVF baby, Louise Brown, took birth. After several decades now, India is known to be a popular surrogacy hub and destination for overseas couples looking for inexpensive infertility treatment (Kotiswaran, 2018). Notably, a whole branch of medical tourism has successfully flourished around the surrogate practice (Bhattacharyya, 2016a, b; India, 2009).

Commercial surrogacy has turned out to be more of a business in India (Sharma, 2007) which makes it a controversial issue altogether with involuntary impacts on women. With the escalating demand for surrogacy, India is a leader in the international surrogacy market which entails substantial profits for those involved. As a result of this, a large number of women have made themselves available as surrogate mothers. Unsurprisingly, these women have been subject to societal discrimination and exploitation, and the lack of definite legislation to regulate the practice of surrogacy has exponentially augmented the plights they face (Pande, 2015). It is seen that the practice of surrogacy leads to exploitation of women in many different ways as it is reckoned to be the easiest and prompt way to earn money. Often, in-laws of a woman compel her to engage in surrogacy in order to earn money.

Further, there have been a large number of reported deaths of women involved in surrogates (Dhillon, 2012). A surrogate mother named Easwari, aged about 30 years died due to excessive bleeding after giving birth to a surrogate baby at a surrogacy clinic in Coimbatore, Tamil Nadu in 2009 (Kusum, 2018). Another surrogate mother, Ranjeeta Lal aged about 29 years who hailed from Hazaribagh was forcefully made the surrogate of her sister-inlaw by her husband and her in-laws. While giving birth to the child she died of a heart attack at Ranchi, Jharkhand (Jaipuriar, 2014).
Another reason for which surrogacy is criticised is that it commodifies women and children (Anderson, 2000). Their abuse goes far beyond inequitable payment to the surrogates into women being forced into C-sections, complications during pregnancy and sometimes even amounting to death (Dhillon, 2012). Evidently, in order to earn extra money and to reduce the chance of failure on the part of the surrogacy clinics, two or more surrogates are planted with embryos. As a result, if multiple women become pregnant, the clinics secretly abort the foetus of the other women and blame them for their carelessness and therefore, do not pay them (Mahardani et al., 2020). An instance of exploitation pertains to the case of an Australian couple that hired an Indian surrogate mother who delivered twins (Rajan, 2014). The couple while returning abandoned one of the children and returned with only one child. It later on came to light that the parents decided to apply for citizenship for only one of the twins. The decision of leaving behind one the babies was based on their preference for a specific gender. Undoubtedly though many couples have benefited from surrogacy facilities, but since this case, the Indian Government has felt the need for proper legislation to tighten and regulate the practice of commercial surrogacy.

As regards legislation, the Supreme Court originally upheld commercial surrogacy in the 2008 case of Baby Manaji v. Union of India (Kusum, 2014). Similarly, in the 2009 Jan Balaz v. Anand Municipality ruling, the Gujarat High Court reiterated the judgment of the apex court by upholding the practice of commercial surrogacy (Kotiswaran, 2018).

Further, the Law Commission, in its 228th report recommended the need for a stringent legislation in order to regulate and control the practice of surrogacy (India, 2009). The Assisted Reproductive Technology (Regulation) Bill was introduced in 2013 to address the overall issue of surrogacy and bring it into the ambit of formal law-making (The Assisted Reproductive Technology (Regulation) Bill, 2013). Failed to pass, this Bill was superseded by the Surrogacy (Regulation) Bill, 2016 and 2019, which banned 
commercial surrogacy in India in contravention with the 2008 Supreme Court ruling (The Surrogacy (Regulation) Bill, 2019). The contravening nature of these bills has led to several debates on whether they appropriately address the rights of surrogate workers, not just mere regulation of the practice (Timms, 2018).

In the era of intensifying human rights jurisprudence, every woman has a right to personal liberty and therefore, every woman has the liberty to act as a surrogate mother mainly because of financial motives. It is to be noted that regarding a woman's right to be a surrogate mother, no explicit mention in any international, as well as national legal documents, has been witnessed so far, although these documents consider a wide range of other issues related to surrogacy. In India, this question bears significance because the nation is a hub for surrogacy practices where an increasing number of poor Indian women are renting their womb and acting as a surrogate mother (Bhattacharyya, 2016a, b; Spar, 2005). This makes it pertinent to determine the fundamental question of whether there is necessity for provisioning of the right to rent a womb and whether the legal foundation of such a right exists in the absence of specific legal recognition. This may make it necessary to review a State's right to interfere in deciding human rights and restrict these rights on the grounds of public interest and morality.

\section{Recognising the Right to Rent a Womb}

The important question that needs answering at present is whether the right to procreate or to bear a child can be extended to include the right of a woman to procreate for another. The word 'personal liberty' was widened by the Supreme Court (Maneka Gandhi v. Union of India, 1978) which held that a variety of rights constitute the personal liberty of a person in the expression 'personal liberty' as found in Article 21 of the Constitution of India (Sehgal, 1995).1 From this analogy, it can be argued that the right of a

\footnotetext{
${ }^{1}$ Article 21 in the Constitution of India refers to the protection of life and personal liberty. No person shall be deprived of her/his life or personal liberty except for according to procedure established by law.
}

woman to rent her womb is included within the ambit of the right to personal liberty and so the right to procreation can be considered as a basic and vital right of an individual. However, in case of certain individuals, the right to procreate can be achieved only by means of Assisted Reproductive Technologies (ART) or with the help of a surrogate woman. Hence, it is logical to state that the right to procreation should include the right to procreate for another. In other words, the right to be a surrogate and the right to rent a womb should be recognised in the interest of the society and vice versa. On the contrary, the social interest must never be overbearing to justify total deprivation of individual liberty (Km. Hema Mishra v. State of UP \& Ors, 2014). Thus, there has to be a balance between the conflicting and competing interests of the society, and that of the individual's liberty to procreate for another, that is, to act as a surrogate mother.

The right of a woman to rent her womb and to act as a surrogate is based on the premise that it is a facet of her personal liberty and it is an exercise of her property right over her own body. It can further be justified on the ground that each and every individual has the right to enjoy the benefits of scientific progress, and the right to enjoy these benefits progress and its applications are incorporated in various international and regional instruments (DixonMueller, 1993). For the first time, this was recognised in Article 13 of the American Declaration of the Rights and Duties of Man, 1948 which endowed every person with the right to enjoy the benefits of scientific progress and its applications (Buergenthal, 1975). This right was further emboldened in Article 27 of the Universal Declaration of Human Rights, 1948 (UNGA, 1948) and clause (1)(b) of Article 15 of the International Covenant on Economic, Social and Cultural Rights (UNGA, 1966).2 Thus, it may be said that every individual has the right to

\footnotetext{
${ }^{2}$ Article 27 of the Universal Declaration of Human Rights states that everyone has the right to freely participate in the cultural life of the community, to enjoy the arts and to share in scientific advancement and its benefits.
} 
enjoy the benefits of scientific progress and its applications.

Seemingly, in 1999, Andhra Pradesh High Court held that the right to make decisions about reproduction is essentially a personal matter ( $B$. K. Parthasarthy v. State of Andhra Pradesh, 1999). In India, right to life and personal liberty of an individual is outlined in Article 21 of the Constitution of India (Bakshi, 2016). By virtue of the said Article, the right of an individual over her/his body is ancillary and such liberty is protected by unlawful interference. Thus, it can be inferred that the individuals have a right over their own body, which confers a woman the right to rent her womb, that is, to be a surrogate mother. However, it should be noted that the property right over the human body is not an absolute right, and may be subject to reasonable restrictions like any other property right.

Further, analysing the right to be a surrogate requires us to know about the process by which surrogacy is accomplished. Surrogacy technique is possible for a woman who do not have a uterus or who have serious medical problems or have been suffering from uterine anomalies impeding her ability to becoming pregnant (Patel et al., 2018). There are two types of surrogacytraditional and gestational surrogacy. In traditional surrogacy, the surrogate mother provides her own egg, which is fertilised by artificial insemination (Thomas, 2009). After that, the surrogate mother carries the foetus and gives birth to a child for another person (India, 2009). The surrogate mother, thus, becomes the biological or genetic mother of the child as she carries the child in her womb until the child is born. On the other hand, in gestational surrogacy, the child carries the genetic combination of both the intending couple (Surrogacy (Regulation) Bill 2019, cl 2(r)) where the genetic mother provides the egg, which is fertilised by IVF in the womb of the surrogate mother. The surrogate mother carries the foetus in her womb and gives birth to the child (India, 2009). Through IVF, also known as a test tube, the chromosome of both the contracting parents are developed in a laboratory as a result of which an embryo is created. Once the zygote is formed, the surrogate mother is implanted with the zygote into her womb. Therefore, in light of these interpretations, it can be stated that when right to privacy and liberty includes the right to make decisions to bear or beget a child, such right should also include the right to rent a womb.

\section{An overview of the Surrogacy (Regulation) Bill, 2019}

On 15 July 2019, Dr. Harsh Vardhan, Minister of Health and Family Welfare introduced the Surrogacy (Regulation) Bill in the Lok Sabha, the lower house (also known as the House of the People) of the Indian Parliament, which bears a bicameral structure. It was passed by the Lok Sabha on 05 August 2019, albeit it was referred to the Select Committee on 21 November 2019. The Select Committee submitted its report on 05 February 2020 (Select Committee Report Summary, 2020). The Surrogacy (Regulation) Bill, which remains in a pending status and is yet to be passed by the Rajya Sabha or the upper house of the Parliament (Council of States) deals primarily with the definition of surrogacy, its regulation and the eligibility criteria for surrogate mothers and intending couples. The Bill states that before an embryo is implanted in the womb of the surrogate, she is required to possess an eligibility certificate which is to be issued by an appropriate authority (The Surrogacy (Regulation) Bill, 2019). An integral part of procuring the eligibility certificate from the appropriate authority is that an intending surrogate shall possess a certificate of medical and psychological fitness. This certificate needs to be issued by a registered medical practitioner adhering to all the legal aspects of the Bill. After birth, the child is handed over to the biological parents by the surrogate mother. Also, a woman wanting to act as a surrogate must be a close relative of the intending couple and should be between 25 to 35 years. Another condition entailing an intended surrogate is that the surrogate shall have a child of her own on the day of implantation.

The Bill allows for altruistic surrogacy and prohibits commercial surrogacy (The Surrogacy (Regulation) Bill, 2019). If a woman receives 
money for agreeing to be a surrogate, it is considered as commercial surrogacy (Timms, 2018). On the contrary, when a woman receives no compensation apart from her medical and other expenses related to pregnancy, along with the insurance coverage, it is referred to as an altruistic. The prohibition of commercial surrogacy and the eligibility criteria have been the main points of contention for the policymakers \& researchers. Contemporary literature argues that the absence of compensation (in altruistic surrogacy) will result in exploitation while inhibiting safe surrogacy services (Bhattacharyya, 2016a; Reddy, 2020).

Further, altruistic surrogacy contracts are currently not governed by any law when examined in light of the Indian Contract Act, 1872 (Samudrala, 2020). Gupta \& Prasad (2019: 299) point out that the Bill fails to address the "physiological and emotional price that surrogates pay" but is "empowering in a limited way" (Bhattacharyya, 2016a, b). They support commercial surrogacy as it "offers women economic opportunities of a scale otherwise denied to them, enabling them to fight a life of poverty" (Gupta \& Prasad, 2019: 299). Moreover, Saini (2020) notes that the Bill is lacking in defining who is a close relative, does not provide provisions for single parents as well as for the LGBTQ community.

\section{Right to be a surrogate vis-à-vis Surrogacy Bill, 2019}

The Surrogacy (Regulation) Bill, 2019, is divided into eight chapters comprising of 51 clauses which deal with the matters related to the regulation and practice of surrogacy. As stated before, one of the critical features of the Bill is that it prohibits commercial surrogacy, and allows altruistic surrogacy. Such restriction

\footnotetext{
${ }^{3}$ Article 13 of the American Declaration states that every person has the right to participate in the benefits that result from intellectual progress, especially scientific discoveries.

${ }^{4}$ Article 27 of the Universal Declaration incorporates cultural rights as human rights and allows for sharing in scientific advancement and its benefits.

${ }^{5}$ Article 15(1)(b) of ICESCR recognises the right to enjoy the benefits of scientific progress and its applications.
}

imposed by virtue of Clause 3(ii) of Surrogacy Regulation Bill, 2019 is inconsistent with Article 13 of the American Declaration of the Rights and Duties of Man, 1948 (Buergenthal, 1975)3; Article 27 of the Universal Declaration of Human Rights, 1948 (UNGA, 1948)4; Article 15 (1)(b) of the International Covenant on Economic, Social and Cultural Rights, 1966 (UNGA, 1966)5; Article 15 of the Universal Declaration on Bioethics and Human Rights, 2005 (UNGA, 1998)6 as well as the Declaration on the Use of Scientific and Technological Progress in the Interests of Peace and for the Benefit of Mankind, 1975 (UNGA, 1975)7. Clause 34(3) of the Assisted Reproductive Technology (Regulation) (ART) Bill, 2008 states that if a woman agrees to act as a surrogate, then such surrogate mother may receive monetary compensation from the intending couple or individual (The Assisted Reproductive Technology (Regulation) Bill, 2008). Similar provisions are solicited under clause 34(3) of the Assisted Reproductive Technologies (Regulation) Bill, 2010 and clause $60(3)(a)$ of the Assisted Reproductive Technology (Regulation) Bill, 2014.

With regard to the age of a surrogate, the Indian Council of Medical Research (ICMR) Guidelines on Surrogacy, Rule 3.10.5, states that a surrogate mother should not be over 45 years of age (Indian Council of Medical Research, 2005). The ART Bill, 2008 was drafted keeping in view the ICMR Guidelines and because of which clause $34(5)$ of the said Bill prescribes the age of the surrogate mother be a minimum of 25 years and a maximum of 35 years. The minimum age to be a surrogate mother is not prescribed in the ICMR Guidelines, but provisions were made for this in the ART Bill, 2008, keeping in mind the health factor of the woman. Further, clause 34(5) of the ART Bill, 2010 states that a woman can be a

\footnotetext{
${ }^{6}$ Article 15 of UDBHR recognises sharing of benefits from any scientific research among the society and the international community, in particular with developing countries.

${ }^{7}$ This declaration encourages all States to promote international cooperation to ensure that results of scientific \& technological developments are used in the interests of strengthening international peace and security, freedom and independence, and also for the purpose of economic and social development of people.
} 
surrogate whose age is not less than 21 years and over 35 years, and shall have at least one live child of her own with a minimum age of three years (Assisted Reproductive Technologies (Regulation) Bill, 2010).

Notably, clause 4(iii)(b)(I) of the Surrogacy (Regulation) Bill, 2016 has stated that the surrogate mother shall be between the age of 25 to 35 years on the day of implantation, and shall be a married woman having a child of her own (The Surrogacy (Regulation) Bill, 2016). Similar provisions have been made under clause 4(iii)(b)(I) of the Surrogacy (Regulation) Bill, 2018 and clause 4(iii)(b)(I) of the Surrogacy (Regulation) Bill, 2019.

Other than the age, marital status is incorporated as another norm for a woman to be a surrogate. Clause 4(iii)(b)(I) of the Surrogacy (Regulation) Bill, 2019 states that only a married woman shall be a surrogate mother or help in surrogacy by donating her egg or oocyte. Clause 34(5) of both the Assisted Reproductive Technology (Regulation) Bill, 2008 and Assisted Reproductive Technologies (Regulation) Bill, 2010 do not deal with the marital status. Only clause 60(5) of Artificial Reproductive Technology (Regulation) Bill, 2014 makes it mandatory for a woman to be married in order to fulfil the eligibility criteria to be a surrogate. Besides, as mentioned above, as per the Surrogacy (Regulation) Bill, 2019, a woman shall have a child of her own in order to fulfil the criterion to be a surrogate. The criterion of having a child with a minimum age of three years was first mentioned in clause 60(5) of the Artificial Reproductive Technology (Regulation) Bill, 2014. This requirement is also provided under clause 4(iii)(b)(I) of Surrogacy Regulation Bill, 2019. Such conditions are not prescribed under the Artificial Reproductive Technology (Regulation) Bill, 2008.

Right to equality, incorporated under Part III of the Constitution of India, states that "the State is prohibited from making any law which takes

\footnotetext{
${ }^{8}$ Article 13 of The Constitution of India refers to laws inconsistent with or in derogation of the Fundamental Rights. Article 13(2) states that "the State shall not make any law which takes away or abridges the rights
}

away or abridges any of the rights conferred by part III" (Bakshi, 2016: 19). Further, Article 13(2)8 expressly lays down that in case of any inconsistency with the laws made by the State and Fundamental Rights, the latter will prevail. Following this, such arbitrary restrictions as imposed under clause 60(5) of Artificial Reproductive Technology Bill, 2014 and clause 4(iii)(b)(I) of the Surrogacy (Regulation) Bill, 2019 violates the liberty of a woman to be a surrogate. The question is, who can act as a surrogate? The next section is an attempt to answer this.

\section{Who can be a surrogate mother?}

It is a delicate issue to ascertain as to who can be a surrogate to beget a child. A bundle of legal and moral issues may arise due to the indiscriminate use of the right by the woman who acts as a surrogate. In 2000, in order to regulate and supervise the Assisted Reproductive Technology (ART) clinics, ICMR and National Academy of Medical Sciences (NAMS) came out with National Guidelines for Accreditation, Supervision and Regulation of ART clinics in India. These guidelines have evolved after detailed discussions and debates by healthcare professionals, experts and practitioners of ART. Moreover, as already discussed above, the Assisted Reproductive Technology (Regulation) Bill, 2008 was introduced for the regulation of ART in India. The Bill did not expressly contain any provision for the eligibility criteria to be a surrogate. However, the definition surrogacy under clause $2(t)$ of the said Bill meant an arrangement in which a (married) woman agrees to be a surrogate that is achieved through ART. In this, in the gametes, shall neither belong to her or her husband. Such a woman shall have the intention to carry the child and hand over the child to the person(s) for whom she is acting as a surrogate. We reiterate here that the 228th Report (India, 2009) had emphasised on the need for adopting specific legislation dealing with surrogacy and thus, the ART Bill, 2010 was drafted. The Bill was reviewed

conferred by this Part and any law made in contravention of this clause shall, to the extent of the contravention, be void" (Bakshi, 2016: 16). 
and redrafted in 2014 and then again in 2017 but was never passed as law.

As per the Surrogacy Bill, 2019, the surrogate shall be a relative of the intended couple or commissioning parents. For instance, in the USA, Lisa Fitzgerald acted as a surrogate for her own sister (Winerip, 2007). However, this can be criticised on the ground that it may amount to degrees of prohibited relationships such as incest or nepotism. Begetting a child by individuals within the degrees of prohibited relationships is generally considered against societal interests. This Bill deals with the regulation of the practice of surrogacy has failed to attend to these sensitive issues, which affect societal interests.

Rule 3.10.6 of the ICMR guidelines state that a relative, a known person, as well as a person unknown to the couple, may act as a surrogate mother for the couple or individual. In the case of a relative acting as a surrogate, the relative should belong to the same generation as the women, who desire a child through surrogacy (Indian Council of Medical Research, 2005). A similar idea is reinforced in clause 34(18) of the ART Bill, 2008 and ART Bill, 2010, which reads as:

A relative, a known person, as well as a person unknown to the couple, may act as a surrogate mother for the couple/ individual. In the case of a relative acting as a surrogate, the relative should belong to the same generation as the women desiring the surrogate.

The word 'may' employed in the said section indicates that a woman does not need to be a relative of the commissioning parents. In other words, it is the discretion of a relative to act as a surrogate. On the contrary, clause 4(iii)(b)(II) of the Surrogacy (Regulation) Bill, 2019 reads as:

no person, other than a close relative of the intending couple, shall act as a surrogate mother and be permitted to undergo surrogacy procedures as per the provisions of this Act.

\footnotetext{
${ }^{9}$ Wet nursing is the practice of breast feeding an infant by a lactating woman when the infant's mother is unable to lactate or in the case the mother is dead. It is an
}

Therefore, the current Bill allows for only a close relative to act as a surrogate, in contrast with the ICMR Guidelines.

Another notable facet mentioned under the rule 3.10.8 of the ICMR Guidelines is that a woman may not act as a surrogate more than thrice in her lifetime. The ART Bill, 2008 does not expressly contain any provision as to how many times a woman can act as a surrogate but its provision to clause $34(5)$ states that a woman shall not act as a surrogate for more than three successful live births in her life. Again, the provision to clause 34(5) of ART Bill, 2010 states that a woman shall not act as a surrogate for more than five successful live births in her life, including her own children. The number of times a woman can be a surrogate has been reduced to one year by virtue of clause 60(5)(a) of ART Bill, 2014, clause 4(iii)(b)(II) of the Surrogacy (Regulation) Bill, 2016, and clause 4(iii)(b)(IV) of the Surrogacy (Regulation) Bill,2 019. This, although meant for the health and welfare of the surrogate mothers, violates Article 21 of the Indian Constitution, besides conventional gender rights and civil liberties.

\section{Economic Perspective on Outlawing Commercial Surrogacy}

Reproductive labour has been a point of contention among economists and policymakers worldwide due to its overlapping characteristics with facets of bodily exploitation, impugning sacralisation and regression of female dignity (Spar, 2005). However, since historical times, reproductive labour has been associated with precarious forms of contractual labour. For instance, the practice of 'wet nursing' 9 in Europe, wherein newborn children were sent away to rural women for suckling or the age-old practice of donating sperm (Johnson \& Rintoul, 2019). These have always been undercompensated forms of labour but were eventually recognised as waged labour. Similar to commercial surrogacy, these are intimate forms of body labour (Pande, 2010) which have been commodified unquestionably. Comparing

ancient practice widely prevalent across all cultures (O'reilly, 2010). 
these forms of body labour with those associated with mining and toxic chemical industries, a section of contemporary literature supports the former arguing that the latter involves lesser compensations, is riskier and takes a heavy toll on their health (Parry, 2018). In this context, banning commercial surrogacy entails no meaning with regard to being exploitative if industrial labour malpractices are not checked through better contract laws.

Similar to India, banning the practice of surrogacy for profit, several developing economies have opted for altruistic surrogacy. This alteration stems from the fact that commercial surrogacy entails in itself a derogatory sentiment for the women practising surrogacy as a source of livelihood. It is no doubt that needy women, especially in countries with high poverty levels, say, India and Thailand, consider renting their womb, not because they believe in the true nature of altruistic motherhood, but due to economic compulsions. In this context, it is debatable whether altruistic surrogacy is more exploitative than commercial surrogacy. Both of them involve similar health as well as psychological costs, besides opportunity costs for the involved women (Galbraith et al., 2005). The mental trauma suffered by an altruistic mother after being separated from her child will be similar to that of a commercial surrogate. However, provision for transaction costs may compensate to an extent in the latter case. Altruism may push this economic activity underground, add to illegal circles of surrogacy and prostitution and augment the black-market economy (Bhattacharyya, 2016a, b). Not surprisingly, existing evidence indicates commercial surrogacy to have higher benefits than costs compared to surrogacy as goodwill.

Besides, commercial surrogacy is considered a better economic solution when it comes to allowing surrogacy within the ambit of income generation. The Surrogacy (Regulation) Bill, 2019, responds rather negatively to the plethora of transaction cost (Verma, 2019) issues that arise in this economic activity. Concerning the regulation of contracts, partial involvement of the state may lead to market distortion and arbitrariness of contractual obligations (Torres et al., 2019). Further, contractual decisions are defined by bounded rationality. Rationality in these cases is bounded by limitedness of available information, influence over the decision, cognitive ability and time available to respond appropriately (Ramskold \& Posner, 2013). This explicitly results in the shift of bargaining power on either side, depending upon the prevailing circumstances. Transaction costs such as the risk of the anticipatory breach also exist in commercial surrogacy that has been ill recognised in the prevailing law. Commercial surrogacy also involves high health risks for women as ART clinics involved in it are mostly unregulated, given the absence of a robust monitoring framework (Bailey, 2011). These clinics give primacy to profits rather than epidemiological needs of patients such as dealing with reproductive tract infections, nutritional requirements of women and essential obstetric services (Kumar et al., 2013). Finally, the act of using the genuine economic need of women while failing to respect their reproductive labour (Sivakami et al., 2019) disregards the entire premise of morality in contracts.

It should be noted that banning commercial surrogacy may push these women into rather economically unrewarding (Reddy, 2020), poorly regulated and potentially hazardous forms of employment than surrogacy. They are at constant risk of being exploited against their will by their families, traffickers and intended couples. For instance, Indian surrogates are paid between $\$ 2,000$ to $\$ 10,000$ for their services whereas the actual surrogacy process costs between $\$ 40,000$ and $\$ 150,000$ of which surrogates are meant to receive a substantial part (Bhattacharyya, 2016a, b; Wilkinson, 2016). In India, a majority part of this sum goes to intermediaries, family members (notably, husbands) and other stakeholders (Grima, 2018) that often look for opportunities to exploit these vulnerable women and earn some money.

\section{Conclusion}

With the progress in Assisted Reproductive Technology, new possibilities for a woman to act 
as a surrogate for another for monetary benefits has gained prominence. However, a ban on commercial surrogacy cannot be justified as a reasonable restriction. It has been found that the Artificial Reproductive Technology (Regulation) Bill, 2008 strictly adheres to the ICMR Guidelines while the Surrogacy (Regulation) Bill, 2019 does not. By comparing the advantage of the Artificial Reproductive Technology (Regulation) Bill, 2008 over the Surrogacy (Regulation) Bill 2019, one can argue that the former upholds the provisions of the Constitution of India. The Surrogacy (Regulation) Bill, 2019 infringes Article 14 of the Constitution of India, which guarantees "equality before law and equal protection of laws to all persons" by restricting surrogacy to only married Indian couples and disqualifying others on the grounds of marital status and close relative, thereby, impinging upon the right to equality for being an unreasonable classification. Further, by disallowing the right to be surrogate to the unmarried people by way of clause 4(iii)(b)(II) of the proposed Surrogacy (Regulation) Bill 2019, the Bill specifically violates the "right of livelihood" as enshrined under the broad framework of Article 21 of the Constitution of India as well as Article 19(1)(g) which guarantees the "freedom of trade and profession" in India as well as various international instruments. Further, ignoring the burgeoning transaction costs of altruistic surrogacy will not only impinge upon a surrogate's right to livelihood but also their right to life and personal liberty. Banning of such rights cannot be imposed arbitrarily. Therefore, the draft Surrogacy Bill, 2019, should be in conformity with the guidelines framed by the ICMR, which may successfully address the right to be a surrogate. This right must be made available to every woman with reasonable restrictions imposed so that such liberty cannot be exercised by a woman arbitrarily.

\section{References}

Anderson, E. S. (2000). Why commercial surrogate motherhood unethically commodifies women and children: reply to McLachlan and Swales. Health care analysis, 8(1), 19-26. https://doi.org/10.1023/A:1009477906883.
B. K. Parthasarthy v. State of Andhra Pradesh, AIR 2000 AP 156.

Bakshi, P. M. (2016). The Constitution of India. New Delhi: Universal Law Publishing.

Bailey, A. (2011). Reconceiving surrogacy: Toward a reproductive justice account of Indian surrogacy. Hypatia, 26(4), 715-741.

https://doi.org/10.1111/j.1527-

2001.2011.01168.x.

Bhattacharyya, R. (2016a). Draft surrogacy (regulation) bill 2016: Rhetoric or surrogatecentric? Space and Culture, India, 4(2), 9-21. https://doi.org/10.20896/saci.v4i2.219.

Bhattacharyya, R. (2016b). Discounted life: The price of global surrogacy in India, Journal Gender, Place and Culture: A Journal of Feminist Geography, 1813-1814.

http://dx.doi.org/10.1080/0966369X.2016.1211 585.

Buergenthal, T. (1975). The revised OAS Charter and the protection of human rights. American Journal of International Law, 69(4), 828-839. https://doi.org/10.2307/2200626.

Dhillon, A. (2012). Mothers for hire. The Sydney Morning Herald, 7. Retrieved 29 May 2020 from, http://www.thelizlibrary.org/surrogacy/120907 -mothers-for-hire.pdf.

Dixon-Mueller, R. (1993). Population policy \& women's rights: Transforming reproductive choice. ABC-CLIO.

Galbraith, M., McLachlan, H. V., \& Swales, J. K. (2005). Commercial agencies and surrogate motherhood: a transaction cost approach. Health Care Analysis, 13(1), 11-31. https://doi.org/10.1007/s10728-005-2567-3.

Ganapathy, N. (2019, 19 August). India's move to ban commercial surrogacy sends industry into panic. The Straits Times, Singapore.

Retrieved on 19 March 2020 from, https://www.straitstimes.com/asia/southasia/indias-move-to-ban-commercial-surrogacysends-industry-into-panic.

Grima, F. M. (2018). Surrogacy: women's empowerment or exploitation? (Master's thesis) University of Malta). Retrieved on 20 March 2020 from, 
https://www.um.edu.mt/library/oar/handle/12 3456789/39970.

Gupta, A., \& Prasad, S. (2019). 'Outsourced pregnancy': Surrogate narratives from Hyderabad. Contributions to Indian Sociology, 53(2), 299-327. https://doi.org/10.1177/0069966719836883 Indian Council of Medical Research. (2005). National Guidelines for Accreditation, Supervision \& Regulation of ART Clinics in India. Government of India. Retrieved on 10 June 2020 from, http://icmr.nic.in/art/art_clinics. India, L. C. (2009). Need for legislation to regulate assisted reproductive technology clinics as well as rights and obligation of parties to a surrogacy. Report No. 228, Government of India, New Delhi. Retrieved on 20 March 2020 from, http://claradoc.gpa.free.fr/doc/180.pdf.

Jaipuriar, V. (2014). Womb rental ends in death. The Telegraph, India. Retrieved on 30 May 2020 from, https://www.telegraphindia.com/states/jharkh and/womb-rental-ends-in-death/cid/164231.

Johnson, C., \& Rintoul, J. (2019). From nursing virgins to Brelfies: the project of maternal femininity. Journal of Gender Studies, 28(8), 918-936.

https://doi.org/10.1080/09589236.2019.16072 67.

Kaur, R. (2015). Surrogacy and its socio legal implications in India (Master's Dissertation, Guru Nanak Dev University, India). Retrieved on 19 March 2020 from, http://hdl.handle.net/10603/160789.

$\mathrm{Km}$. Hema Mishra vs State of UP \& Ors, AIR 2014 SC 146.

Kotiswaran, P. (2018). Law's Paradoxes: Governing Surrogacy in India. In Cross-Cultural Comparisons on Surrogacy and Egg Donation (pp. 127-151). Palgrave Macmillan, Cham.

Kumar, P., Inder, D., \& Sharma, N. (2013).

Surrogacy and women's right to health in India: Issues and perspective. Indian Journal of Public Health, 57(2), 65.

https://doi.org/10.4103/0019-557x.114984
Kusum, S. (2013). Commercial Surrogacy and Feminist Perspectives. Karnataka Law Journal, 1(13). Retrieved on 7 June 2020 from, https://writingsonsurrogacy.wordpress.com/20 16/10/18/commercial-surrogacy-feministperspectives/.

Kusum, S. (2014). Legal Glitches Facing Surrogacy Agreement in India. Indian Journal of Law \& Public Policy, 1, 26.

https://heinonline.org/HOL/LandingPage?handl e=hein.journals/ijlpp1\&div=19\&id=\&page=.

Kusum, S. (2018, 24 April). What If the Surrogate Mother Dies? The Economic Times, India. Retrieved on 25 April 2020 from, https://health.economictimes.indiatimes.com/n ews/industry/what-if-the-surrogate-motherdies-sonali-kusum/63897209.

Kumar, T. A. (2004). In vitro fertilization in India. Current Science, 86(2), 254-256. Retrieved on 30 May 2020 from, https://www.jstor.org/stable/24107860.

Mahardani, N. P. T., Putra, B. A., Syahdan, P., Ismail, S., \& Burhanuddin, A. (2020). Process and problems of the international adoption in surrogacy cross-border practices in India. Enfermería Clínica, 30, 115-118. https://doi.org/10.1016/j.enfcli.2019.07.058 Maneka Gandhi v. Union of India, AIR 1978 SC 597.

O'reilly, A. (2010). Encyclopedia of motherhood. Sage Publications, CA.

Pande, A. (2010). Commercial surrogacy in India: Manufacturing a perfect motherworker. Signs: Journal of Women in Culture and Society, 35(4), 969-992.

https://doi.org/10.1086/651043.

Pande, A. (2014). Wombs in labor:

Transnational commercial surrogacy in India. Columbia University Press. https://doi.org/10.7312/pand16990.

Pande, A. (2015). Blood, sweat and dummy tummies: Kin labour and transnational surrogacy in India. Anthropologica, 57(1), 53-62. www.jstor.org/stable/24470912.

Parry, B. (2018). Surrogate labour: exceptional for whom?. Economy and Society, 47(2), 214233. 
https://doi.org/10.1080/03085147.2018.14871 80.

Patel, N. H., Jadeja, Y. D., Bhadarka, H. K., Patel, M. N., Patel, N. H., \& Sodagar, N. R. (2018). Insight into different aspects of surrogacy practices. Journal of Human Reproductive Sciences, 11(3), 212. https://doi.org/10.4103/jhrs.jhrs_138_17. Qadeer, I. (2010). Benefits and threats of international trade in health: A case of surrogacy in India. Global Social Policy, 10(3), 303-305.

https://doi.org/10.1177/146801811001000302 06.

Rajan, S. (2014). Resolving Statelessness Arising out of Surrogacy in India: A Legal Analysis. International Human \& Refugee Law, 14, 177. Retrieved 5 June 2020 from, https://heinonline.org/HOL/LandingPage?handl e=hein.journals/isilyrbk13\&div=10\&id=\&page=. Ramskold, L. A. H., \& Posner, M. P. (2013). Commercial surrogacy: how provisions of monetary remuneration and powers of international law can prevent exploitation of gestational surrogates. Journal of medical ethics, 39(6), 397-

402.https://doi.org/10.1136/medethics-2012100527.

Reddy, J. (2020). Indian surrogacy: Ending cheap labour. Santa Clara Journal of International Law, 18(1), 92. Retrieved on 19 March 2020 from, https://digitalcommons.law.scu.edu/cgi/viewco ntent. cgi?article $=1236 \&$ context $=$ scujil .

Rwabihama, J. P., Belmin, J., Hagege, M., Audureau, E., Benzengli, H., Ambime, G., ... \& Sagar, S. (2017). Indian law and policy on surrogacy: A socio-legal study with special reference to Bareilly and Moradabad. Unpublished Doctoral thesis, Dr. BR Ambedkar University, India.

Saini, A. (2020). Surrogacy laws in India: Legality and validity as per law. Our Heritage, 68(30), 1830-1835. Retrieved on 08 February 2020 from https://archives.ourheritagejournal.com/index. php/oh/article/view/3575.
Samudrala, S. (2020). Altruistic surrogacy contracts: legal analysis of The Surrogacy (Regulation) Bill, 2019 and its legal implications. Christ University Law Journal, 9(1), 73-97. Retrieved on 19 March 2020 from, http://111.93.136.232/index.php/culj/article/vi ew/2208.

Sehgal, B. P. S. (1995). Human rights in India: problems and perspectives. New Delhi: Deep and Deep Publications.

Select Committee Report Summary for The Surrogacy (Regulation) Bill, 2019. (2020). PRS Legislative Research, Government of India. Retrieved on 28 May 2020 from, https://www.prsindia.org/billtrack/surrogacyregulation-bill-2019.

Sharma, R. (2007). An International, Moral \& Legal Perspective: The Call for Legalization of Surrogacy in India. Moral \& Legal Perspective: The Call for Legalization of Surrogacy in India (July 2, 2007).

Sivakami, N., Kanchana, P. N., \& Barclay, F. P. (2019). Social Constructs of Surrogacy: The Indian Perspective. Health, Safety and WellBeing of Workers in the Informal Sector in India, 187-196, Singapore: Springer.

https://doi.org/10.1007/978-981-13-84219_15.

Spar, D. (2005). For love and money: the political economy of commercial surrogacy. Review of International Political Economy, 12(2), 287-

309.https://doi.org/10.1080/096922905001056 15.

The Assisted Reproductive Technology (Regulation) Bill, 2008 (pending). Retrieved on 10 June 2020 from, https://www.prsindia.org/uploads/media/vikas _doc/docs/1241500084 DraftARTBill.pdf.

The Assisted Reproductive Technologies (Regulation) Bill, 2010 (pending). Retrieved on 10 June 2020 from, https://main.icmr.nic.in/sites/default/files/guid elines/ART\%20REGULATION\%20Draft\%20Bill1.p df.

The Assisted Reproductive Technology (Regulation) Bill, 2013 (pending). Retrieved on 10 June 2020 from, http://ncw.nic.in/ncw- 
cells/legal-cell/new-bills-laws-proposed/newbills-law-

proposed\#: :text=The\%20Indian\%20Council\%2 Oof\%20Medical,a\%20Member\%20in\%20this\%2 0Committee.

The Surrogacy (Regulation) Bill, 2016 (passed by Lok Sabha, 19/12/2018). Retrieved on 9 June 2020 from,

https://www.prsindia.org/billtrack/surrogacyregulation-bill-2016.

The Surrogacy (Regulation) Bill, 2018 (pending). Retrieved on 9 June 2020 from, http://164.100.47.4/BillsTexts/LSBillTexts/Passe dLoksabha/257-C\%20_2016_Eng..pdf.

The Surrogacy (Regulation) Bill, 2019 (passed by Lok Sabha, 05/08/2019). Retrieved on 15 March 2020 from,

http://www.cnlu.ac.in/2016/Notices/MOOTS/SI LC\%20Format.pdf.

Thomas, M. (2009, 02 November). Outsourcing surrogacy. The Hindu, India.

https://www.thehindu.com/opinion/openpage/Outsourcing-

surrogacy/article16889820.ece.

Timms, O. (2018). Ending commercial surrogacy in India: significance of the Surrogacy

(Regulation) Bill, 2016. Indian Journal of

Medical Ethics, 3, 99.

https://doi.org/10.20529/ijme.2018.019.

Torres, G., Shapiro, A., \& Mackey, T. K. (2019). A review of surrogate motherhood regulation in south American countries: pointing to a need for an international legal framework. $B M C$ Pregnancy and Childbirth, 19(1), 46. https://doi.org/10.1186/s12884-019-2182-1.

UN General Assembly. (1948). Universal Declaration of Human Rights. United Nations, 302(2). https://doi.org/10.4337/9781845428297.00024

UN General Assembly. (1966). International Covenant on Economic, Social and Cultural Rights. United Nations, 993, 3.

https://doi.org/10.4337/9781845428297.00026
UN General Assembly. (1975). Declaration on the Use of Scientific and Technological Progress in the Interests of Peace and for the Benefit of Mankind. United Nations, Paris. https://digitallibrary.un.org/record/189603?!n= en.

UN General Assembly. (1998). Universal Declaration on Bioethics and Human Rights. United Nations Educational, Scientific and Cultural Organization, Geneva.

https://en.unesco.org/themes/ethics-scienceand-technology/bioethics-and-human-rights.

Van den Akker, O. B. (2017). Surrogate motherhood families. Palgrave Macmillan, New York. https://doi.org/10.1007/978-3-31960453-4.

Verma, A. (2019). Social implications of surrogacy in India. Research Journal of Social Sciences, 10(7). Retrieved on 19 March 2020 from, https://www.ijitee.org/wpcontent/uploads/papers/v8i12/L33261081219. pdf.

Vincent, C., \& Aftandilian, A. D. (2013). Liberation or exploitation: commercial surrogacy and the Indian surrogate. Suffolk Transnat'I L. Rev., 36, 671.

https://heinonline.org/HOL/LandingPage?handl $\mathrm{e}=$ hein.journals $/$ sujtnIr36\&div=32\&id=\&page= .

Watson, C. (2016). Womb Rentals and BabySelling: does surrogacy undermine the human dignity and rights of the surrogate mother and child?. The New Bioethics, 22(3), 212-228. https://doi.org/10.1080/20502877.2016.12385 82.

Wilkinson, S. (2016). Exploitation in international paid surrogacy arrangements. Journal of Applied Philosophy, 33(2), 125-

145. https://doi.org/10.1111/japp.12138 .

Winerip, M. (2007, 23 December). My sister, my surrogate. The New York Times, United States of America. Retrieved on 10 February 2020 from, https://www.nytimes.com/2007/12/23/nyregio n/nyregionspecial2/23Rparent.html. 